Journal of Contemporary Research in Social Sciences

ISSN : 2641-0249

Vol. 2, No. 4, pp. 68-80.

2020

Publisher: Learning Gate

DOI: 10.33094/26410249.2020.24.68.80

(C) 2020 by the authors; licensee Learning Gate

\title{
Empowerment of the Extreme Poor Women through Microfinance: Evidence from Northern Part of Bangladesh
}

\author{
Mesbahuddin Ahmed \\ Palli Karma-sahayak Foundation (PKSF), Dhaka, Bangladesh. \\ Anu Muhammad Anisur Rahman \\ Department of Economics, Jahangirnagar University, Dhaka, Bangladesh. \\ Most Nilufa Khatun \\ Department of Agricultural Finance and Cooperatives, Bangabandhu Sheikh Mujibur Rahman Agricultural University, Gazipur, \\ Bangladesh. \\ Email:nilufa@bsmrau.edu.bd
}

Received: 3 September 2020; Revised: 28 September 2020; Accepted: 12 October 2020; Published: 26 October 2020

\begin{abstract}
Women's empowerment is a crucial enabler for alleviating poverty. Microfinance is considered as a key tool for empowering women by improving access to economic and social activities. This study explores the role of microfinance for economic and social empowerment of the rural extreme poor women using primary data collected from Rangpur division of Bangladesh. Economic and social empowerment are measured using three and four indicators, respectively. Effectiveness of microfinance programs are examined using simple comparison as well as statistical analysis. Result shows that overall women's empowerment condition is not satisfactory in the study area. However, microfinance participants enjoy relatively more economic and social empowerment than non-participants. The study also reveals that a significant use of microcredit empower the rural women significantly. Statistical analysis shows that almost all indicators are positively and significantly related to microfinance programs. More emphasis should be put on using borrowed money effectively by the program participants for income generating activities in order to make the poor women empowered.
\end{abstract}

Keywords: Bangladesh, Extreme poor, Economic condition, Microfinance, Women's empowerment.

\section{Introduction}

Bangladesh is a populous South Asian country which has $147570 \mathrm{~km}^{2}$ land and 936 persons $/ \mathrm{km}^{2}$ density. Almost half of its population are women and about 30\% people living under poverty line (BBS, 2014). Backwardness of women is one of the important reasons for not getting expected rank in human development. Rural women in Bangladesh usually remain socially and economically dependent on men. Generally women in Bangladesh are dependent on father, husband, and son for economic security at different stages of life due to the culture of seldom earning (Eze, 2019). From early childhood, women confront discrimination in everyday life such as in feeding, clothing, schooling, moving, and behaving due to the existing social and cultural norms (Shafi, Sarker, \& Junrong, 2019) which are the main root of deprivation (Sarker et al., 2018). Deprivation leads to discrimination that prevails in getting job and earning opportunities, assets, wage earning, and access to food and resources (Alam, 2016; Pitt \& Khandker, 1996). This discrimination constrains women's potential to generate incomes and to contribute to the economy (Kamruzzaman et al., 2020). Women's empowerment is much talked issue in policy agenda which reflects a state of material well-being that includes increased income and savings, ownership of assets and properties, decision-making ability, improved healthcare and education, 
unrestricted mobility, and freedom from domination and violence. Scholars also define empowerment as belongingness to resources (economic, physical, institutional, and human) and ideologies (like attitudes, beliefs, and values) (Hultberg, 2008).

Due to the gender specific barriers and socio-economic and cultural disparities, rural women in the society remain the most vulnerable section in Bangladesh (Alam, Monirul Alam, \& Mushtaq, 2018; Khatun, 2017; Mersland, Nyarko, \& Szafarz, 2019; Sarker, Yang, Lv, Enamul, \& Kamruzzaman, 2020b). Poverty incidence is comparatively severe and acute among women than men(Khanam, Mohiuddin, Hoque, \& Weber, 2018). Microfinance programs mainly deal with those disposed women and provides social and financial intermediation to address the issues related to poverty alleviation (Sofi \& Sumaira, 2016), financial support to initiate microenterprises, and overall gender development (Hoque, 2014).

Several studies revealed that microfinance contributes to women's empowerment (For example, (Ghosh \& Bhandari, 2014; Khatun, 2017; Pitt \& Khandker, 1996; Singh \& Padhi, 2019; Weber \& Ahmad, 2014). Some researcher, on the other hand, argued that microfinance disempowers women (Goetz \& Gupta, 1996; Mohindra, Haddad, \& Narayana, 2008). Despite massive expansion of microfinance program, debates about its effectiveness on empowering women are still ongoing. So, more solid empirical research is needed covering the grassroots experiences for comprehensive understanding of the effectiveness of microfinance programs on women's empowerment. The present study addresses the issues of economic and social empowerment of the extreme poor women and how women's empowerments are related to participation in microfinance programs. The following research objectives were set to achieve overall goal of the study:

i. To evaluate the impact of microfinance activities in empowering extreme poor women.

ii. To illustrate the policy implications and suggestions for future action.

The paper is ordered as follows: Section II presents descriptions of the study areas, the method of data collection and the data analysis; Section III provides the results and discussion; and section IV provides conclusions and policy implications.

\section{Methodology}

\subsection{Study Area and Sampling Technique}

For this study Monga ${ }^{1}$ prone area of Northern Bangladesh i.e. Rangpur division was selected as the study area Figure 1. Rangpur division is an administrative unit covering five districts namely, Kurigram, Gaibandha, Lalmonirhat, Nilphamari and Rangpur.

In order to maintain consistency and to compare empowerment status with and without microfinance, homogenous group of both participants and non-participants were selected carefully. In 2006, Palli Karma-sahayak Foundation (PKSF) conducted a census to identify people who are extreme poor and affected by Monga. A total of 19,59,249 households were found in Rangpur division in this census. Then sorted out of 4,82,984 extreme poor and monga affected households from this census data by using following criteria- (i) households having monthly income less than Tk. 1500, and/or (ii) One of the earning members is working as day-labourer, and/or (iii) Household's maximum land holding is 50 decimal. Those who had all or at least one of these criteria was considered as vulnerable, extreme poor and affected by Monga. This database of extreme poor was used as population in this study. PKSF authority permitted to use this database only for the present study.

Multistage random sampling technique was followed to draw the sample from this population. In the first stage, three districts out of entire five districts of Rangpur division were considered. In the second stage, two upazilas of each district were selected. In the third stage, two unions of each upazila were selected which resulted in 12 unions in total. Finally, 142 participant and 137 non-participant households were selected randomly from those 12 unions.

\footnotetext{
${ }^{1}$ Monga is a periodical famine due to unavailability of earning source and lack of food usually happened in a period from Mid-September to MidNovember in the north of Bangladesh (PKSF, 2007).
} 


\subsection{Questionnaire and Data Collection}

A draft interview schedule was prepared in such a way that fulfill the objectives of the study. The draft schedule was pre-tested with 10 households in the selected unions. The schedule was then finalized after necessary correction, modification and adjustments. In this study, mainly economic and social empowerment of women were considered. Both empowerment were measured by structured questions i.e. respondents answered the questions within a given options related to empowerment.

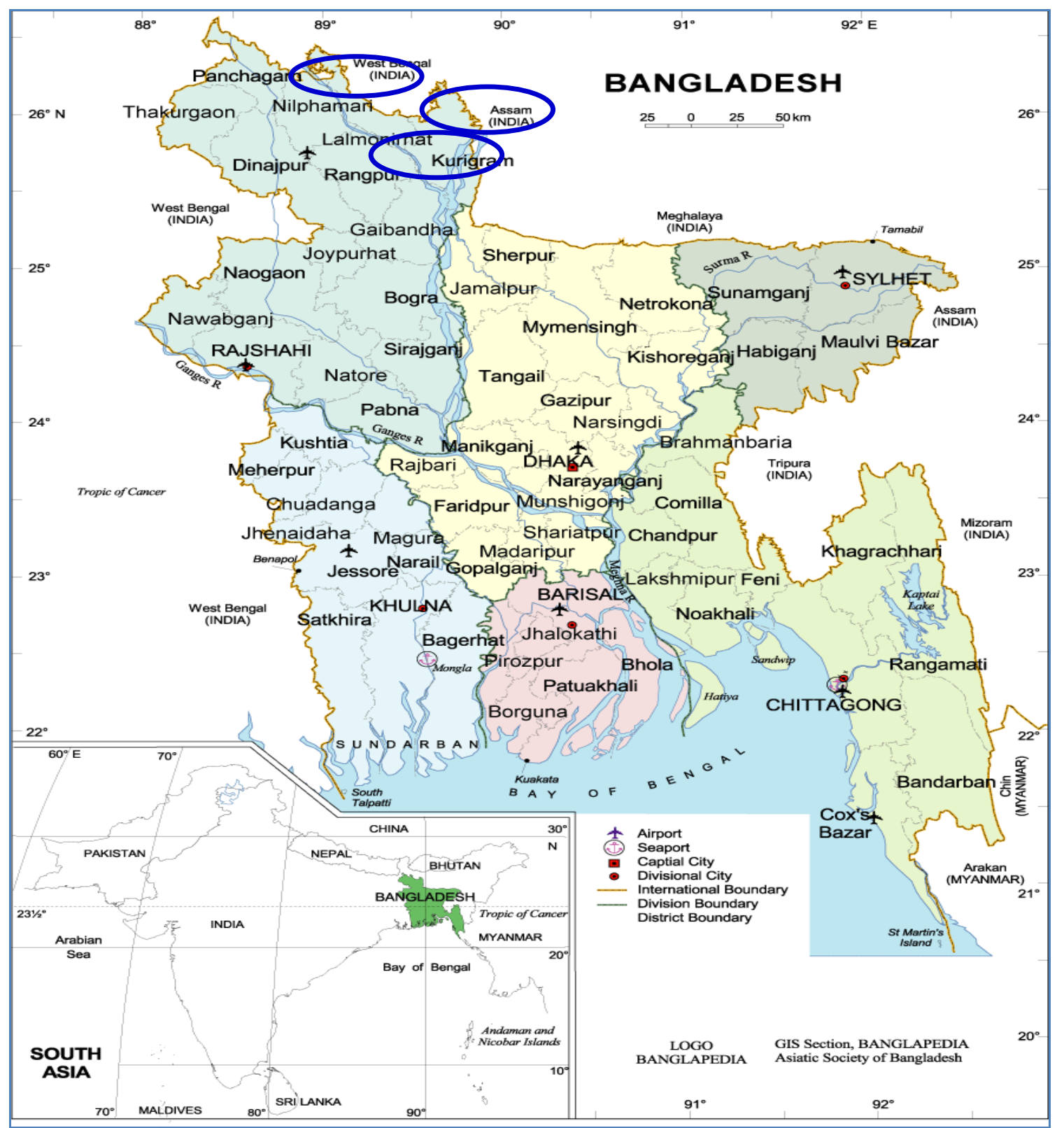

Figure-1.

The Map of Bangladesh showing the study area.

Source: Banglapedia (https://www.pinterest.com/pin/624241198325541590/)

After finalizing the interview schedule, the primary data were collected through field survey from both microfinance participants and non-participants during November 2012 to February 2013. 
Household head was the survey respondent. The first author along with two trained enourametors took part in the data collection. To overcome errors, and to ensure accurecy of collected data all possible efforts were made by the researchers such as checking the interview schedules in each day and drawing histrogram. Thus, information obtained for the present study is fairly reliable.

\subsection{Selection of the Measurement Indicators for Women's Empowerment}

Women's empowerment is a multidimensional concept (Malhotra \& Schuler, 2005). Empowerment is the achieving power and authority. Women empowerment thus focuses on the achieving power and authority of the women (Islam, 2014). However, formulating a valid and reliable measure of women's empowerment is difficult due to social norms, geography, economic opportunities, human behavior, beliefs, and attitudes which varies significantly among societies. There are a number of studies (Hulme \& Moore, 2007); (Hultberg, 2008; Islam, 2014; Khanam et al., 2018) that measured the empowerment status of women, however, none of these is out of criticism. Most of the previous studies capture some 'possible slice of empowerment than empowerment itself (Malhotra \& Schuler, 2005). As a matter of fact, it is not possible for a single study to include all relevant indicators of women's empowerment.

Table-1.

Empowerment indicators and measurement.

\begin{tabular}{|c|c|c|c|c|}
\hline $\begin{array}{l}\text { Serial } \\
\text { no. }\end{array}$ & $\begin{array}{l}\text { Empowerment } \\
\text { indicators }\end{array}$ & $\begin{array}{c}\text { Items } \\
\text { used }\end{array}$ & $\begin{array}{lll}\text { Responses and assigned } \\
\text { scores }\end{array}$ & $\begin{array}{c}\text { Possible score } \\
\text { range }\end{array}$ \\
\hline \multicolumn{5}{|c|}{ Economic empowerment: } \\
\hline 1. & Financial decision making & 4 & $\begin{array}{l}\text { Full influence (3), Moderate } \\
\text { influence }(2) \text {, Low influence }(1) \text {, } \\
\text { No influence }(0)\end{array}$ & $0-12$ \\
\hline 2. & $\begin{array}{l}\text { Independent purchasing } \\
\text { capability }\end{array}$ & 8 & $\begin{array}{l}\text { Capable without asking for her } \\
\text { husband's permission (3), } \\
\text { Capable with husband's } \\
\text { permission (2), Incapable (1), } \\
\text { Assaulted if practices (O) }\end{array}$ & $0-24$ \\
\hline 3. & Economic security & 5 & $\begin{array}{l}\text { Fully enjoyed (3), Moderately } \\
\text { enjoyed (2), Partially enjoyed } \\
(1) \text {, Enjoyed nothing (o) }\end{array}$ & $0-15$ \\
\hline \multicolumn{5}{|c|}{ Social Empowerment: } \\
\hline 1. & Decision making & 7 & $\begin{array}{l}\text { Full influence (3), Moderate } \\
\text { influence }(2) \text {, Low influence }(1) \text {, } \\
\text { No influence }(0)\end{array}$ & $0-21$ \\
\hline 2. & $\begin{array}{l}\text { Relative freedom from } \\
\text { domination and violence } \\
\text { within the family }\end{array}$ & 6 & $\begin{array}{l}\text { Not at all (3), Rarely (2), } \\
\text { Occasionally (1), Frequently (O) }\end{array}$ & $0-18$ \\
\hline 3. & Cosmopoliteness & 10 & $\begin{array}{l}\text { Frequently (3), Occasionally } \\
(2) \text {, Rarely (1), Not at all (O) }\end{array}$ & $0-30$ \\
\hline 4. & $\begin{array}{l}\text { Community, social and } \\
\text { political participation }\end{array}$ & 8 & $\begin{array}{l}\text { Frequent participation }(3) \text {, } \\
\text { Occasional participation (2), } \\
\text { Seldom participation (1), No } \\
\text { participation (o) }\end{array}$ & $0-24$ \\
\hline
\end{tabular}

Source: Field survey.

This study has selected seven indicators of empowerment in the light of available literature review (Bekele \& Muchie, 2009; Ghosh., 2013; Hoque, 2014; Nawaz, 2019; Richardson, 2018; Roodman \& Morduch, 2014; Weber \& Ahmad, 2014), extensive observation, and personal interviews with the 
respondents. Among these seven indicators, first three (i.e. financial decision making, independent purchasing capacity, economic security) were used to measure economic empowerment and rest four (i.e. decision making in social and family affairs; relative freedom from domination and violence within the family; cosmopoliteness; and community, social and political participation) were used to measure social empowerment. These seven indicators were measured by using total 48 items Appendix-1. Each of these 48items captured the sample respondent's perceived level of empowerment with a 4-point range, considering their present situations with and without participation in the microfinance programs.

\subsection{Measurement Technique of Scores of Empowerment Indicators}

A respondent's empowerment score in each of the seven empowerment indicators was calculated by adding the separate scores reported for all items in that dimension. Respondents were requested to response in each items of the above mentioned seven indicators. Their answers were recorded along a 4point continuum.

A respondent's economic and social empowerment score was calculated by calculating the total scores from three and four indicators, respectively. Economic empowerment could range from 0 to 51 , with ' $O$ ' denoting no empowerment and ' 51 ' representing the highest level of empowerment. Social empowerment could range from 0 to 93, with ' 0 ' denoting no empowerment and '93' representing the highest level of empowerment. To permit comparison among the dimensions of empowerment, the following formula was used to compute a unit score for each:

Unit empowerment score $=\frac{\text { Mean score of a particular dimension }}{\text { Maximum possible score of the dimension }}$

\subsection{Econometric Analysis}

Along with the numeric descriptive measures, a statistical relation was also made between program participation and empowerment dimensions using Logit regression model as follows (Equation 1):

$$
\operatorname{Ln}\left(\frac{\emptyset_{i}}{1-\emptyset_{i}}\right)=\beta_{0}+\sum_{j=1}^{n=k} \beta_{j} x_{i j}+\varepsilon_{i}
$$

Where, $\emptyset_{\mathrm{i}}$ means the conditional probability of extreme poor women's participation to microfinance program or not (program participation $=1$ and 0 ; otherwise), $\beta_{\mathrm{j}}$ 's are the parameters to be calculated and $\mathrm{X}_{\mathrm{ij}}{ }^{\prime} \mathrm{s}$ are the independent variables and $\boldsymbol{\varepsilon}_{\mathrm{i}}$ means an error term which is supposed to be uncorrelated with the explanatory variables.

Use of logistic regression (Cramer, 2003) was consistent to previous research (Bekele \& Muchie, 2009; Binaté Fofana, Antonides, Niehof, \& van Ophem, 2015; Garrity \& Martin, 2018; Khatun, 2017; Lavoori \& Paramanik, 2014; Murshid \& Ball, 2018; Nawaz, 2019; Zafarullah \& Nawaz, 2019). Z test examined the significance of the relationships between microfinance program participation and empowerment indicators. The issues of collinearity and multocollinearity were checked and found within the acceptable conventional threshold level to proceed further.

\section{Results and Discussions}

\subsection{Socio-Economic Background of Households}

Brief socio-demographic characteristics of the sample households are presented below:

- Almost 68 percent of the household heads were in the productive age group of 19-50 years. The highest 28.0 percent and lowest 14.0 percent of the head of households were in the age group of 31 to 40 years and above 60 years respectively.

- Overall 74.67 percent of the household's head were illiterate. Only 18.33 percent of the head of households had schooling range between 1-8 years and a negligible ( 5 percent) portion had schooling range 9-10 years. Average schooling of the head of sample households was 1.44 years.

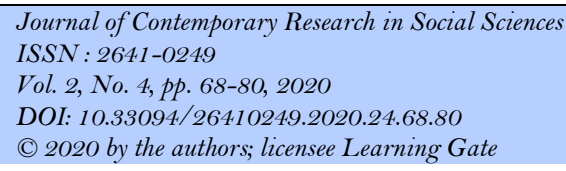


- The highest 42.67 percent of the sample households had family size up to 4 persons and lowest 5 percent had family size of more than 8 . Average family size was found to be 4.50 , which is larger than the national average of 4.48 .

- About 10.0 percent of the sample households had no homestead land. Only 77.67 percent of the households had only homestead land. About 10.0 percent had homestead and land not more than 0.50 acre. Only 2.33 percent had homestead and land more than 0.50 acre. Average land holding of the households was 10.96 decimal.

- More than thirteen Microfinance Institutions (MFIs) were used by the 142 participant sample households. Among them 20 percent was taken loan from Grameen Bank, 15.29 percent from ASA, 10.0 percent from SKS, and 9.41 percent from BRAC. However, 20 households took loans from more than one source.

\subsection{Economic Empowerment}

Economic empowerment of the extreme poor women with and without participation in microfinance program are presented below:

\subsection{Financial Decision Making}

The study found that the women in the study area were not fully permitted to make their own decisions, and thus became dependent on the approval of their male partners if they desired to participate in economic activities. However, the unit score of empowerment in the financial decision making was found relatively little higher for microfinance program participants (0.38) than nonparticipants (0.33) Table 2.

\subsection{Independent Purchasing Capability}

Results in the Table- 2 shows that participants (0.41) enjoyed more purchasing capability than that of non-participants (0.35) Table 2. At the time of receiving loan in cash, participants' gained some power to purchase according to their desire. Since MFIs distributed the money specifically to the women, in some cases their male counterparts did not interfere in their small purchases. In this scenario, microfinance program contributed to the purchasing capability of women. On the other hand, nonparticipants women generally do not retain cash on hand. They used to maintain their household expenditures mainly with the daily earnings of their husbands. As a result, they do not get opportunity to contribute in small purchasing like microfinance program participants.

Table-2.

Economic empowerment scores with and without participation in microfinance program.

\begin{tabular}{|c|c|c|c|c|c|}
\hline \multirow[b]{2}{*}{ Empowerment dimensions } & \multirow{2}{*}{$\begin{array}{c}\text { Possible } \\
\text { score range }\end{array}$} & \multicolumn{2}{|c|}{ Participants } & \multicolumn{2}{|c|}{ Non- participants } \\
\hline & & $\begin{array}{l}\text { Mean } \\
\text { score }\end{array}$ & $\begin{array}{l}\text { Unit } \\
\text { score }\end{array}$ & $\begin{array}{l}\text { Mean } \\
\text { score }\end{array}$ & $\begin{array}{l}\text { Unit } \\
\text { score }\end{array}$ \\
\hline Financial decision making & $0-12$ & 4.56 & 0.38 & 3.95 & 0.33 \\
\hline $\begin{array}{l}\text { Independent purchasing } \\
\text { capability }\end{array}$ & $0-24$ & 9.85 & 0.41 & 8.35 & 0.35 \\
\hline Economic security & $0-15$ & 4.16 & 0.28 & 3.39 & 0.23 \\
\hline Overall & $0-51$ & 18.57 & 0.36 & 15.69 & 0.31 \\
\hline
\end{tabular}

Source: Field survey. 


\subsection{Economic Security}

MFIs always try that the assets that is built using the borrowed money must be named after borrower women's name. This practice also empowers women temporarily compared to nonparticipants. The study found evidence that participants (0.28) enjoyed more economic security than non-participants (0.23) Table 2.

\subsection{Social Empowerment}

Social empowerment of the women with and without participation in microfinance program are narrated below:

\subsection{Decision Making in Social and Family Affairs}

The weight of empowerment in the decision making ability in social and family affairs of the participants (0.47) and non-participants (0.41) illustrates that participants were in better position compared to non-participants Table 3. This is because MFIs make awareness to their members about education, health and family planning etc. Few MFIs have credit plus different health and education programs with the same beneficiaries.

\subsection{Relative Independence from Domination and Violence within the Family}

The study results show that participants in the study areas enjoyed relative freedom $(0.50)$ in the family compared to non-participants (0.42) Table 3. Findings also reveal that microfinance program participation reduce violence against women in the family, increase opportunity to move free where necessary and earn relative importance to her husband and other household members. Taking loan from MFIs enable them to start any income generating activities or can help to strengthen existing income generating activities of a member's husband. This contributed to make them free from domination and violence within the family.

Table-3.

Social empowerment scores with and without participation in microfinance program.

\begin{tabular}{l|c|c|c|c|c}
\hline \multirow{2}{*}{ Empowerment dimensions } & \multirow{2}{*}{$\begin{array}{c}\text { Possible } \\
\text { score } \\
\text { range }\end{array}$} & \multicolumn{2}{|c|}{ Participants } & \multicolumn{2}{|c}{ Non-participants } \\
\cline { 3 - 6 } & Mean & Wight & \multicolumn{2}{c}{$\begin{array}{c}\text { Mean } \\
\text { score }\end{array}$} & Wight \\
\hline $\begin{array}{l}\text { Decision making in social and family } \\
\text { affairs }\end{array}$ & $0-21$ & 9.90 & 0.47 & 8.53 & 0.41 \\
\hline $\begin{array}{l}\text { Relative freedom in the family } \\
\text { Cosmopoliteness }\end{array}$ & $0-18$ & 8.95 & 0.50 & 7.48 & 0.42 \\
\hline $\begin{array}{l}\text { Community, social and political } \\
\text { participation }\end{array}$ & $0-30$ & 8.73 & 0.29 & 7.75 & 0.26 \\
\hline \begin{tabular}{l} 
Overall \\
\hline
\end{tabular} & $0-93$ & 34.23 & 0.37 & 29.46 & 0.24 \\
\hline
\end{tabular}

Source: Field survey.

\subsection{Cosmopoliteness}

Survey findings also show that participants (0.29) enjoyed comparatively more cosmopoliteness than non-participants (0.26) Table 3. The reasons are that participants had to attend MFI offices and group meetings more frequently than non-nonparticipants in order to receive services. Moreover taking loan money from MFI creates opportunity for a participant woman to buy something for her family and

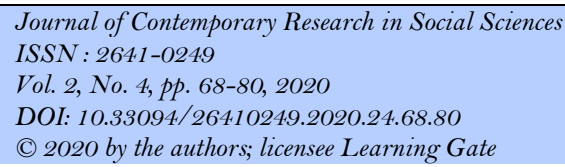


to start income generating activities (Sarker, Wu, Alam, \& Shouse, 2020a). These activities help to improve cosmopoliteness of participant women compared to non-participants.

\subsection{Community, Social and Political Participation}

Results in the Table 3 shows that participants had better (0.28) participation in social, political, and community activities- e.g., participation in marriage ceremonies, and birthday party, helping neighbors, and arbitration in the conflicts of neighbors and family than the non-participants (0.24) Table 3. The results reveal that participation in microfinance program provides participants financial solvency as well as social status.

\subsection{Economic Empowerment Status}

The total economic empowerment score of a woman was computed by adding the scores obtained from three measures of economic empowerment. Possible scores ranged from 0 to 51 . Empowerment score of the respondents was classified into four categories such as: Very low empowerment (up to 10), Low empowerment (11 to 20), Medium empowerment (21 to 30) and High empowerment (Above 30) Figure 2.

Figure 2 indicates that about 26.06 percent of the participants reached to the level of medium empowerment that is higher than the non-participants (16.06\%). Only 7.75 percent of the participants were able to uplift their status to high empowerment. On the other hand, 11.68 percent of the nonparticipants were able to uplift their status to high empowerment. The majority of the both group remained in the "very low" level of empowerment category. About 50.70 percent of the participants and 54.74 percent of the non-participants remained in the group 'very low' category Figure 2. This figure reveals that microfinance program empowered rural women in medium scale. Only some better-off members could uplift their empowerment status both in the family and society. Despite this achievement, levels of women empowerment generally remains below than expectation.

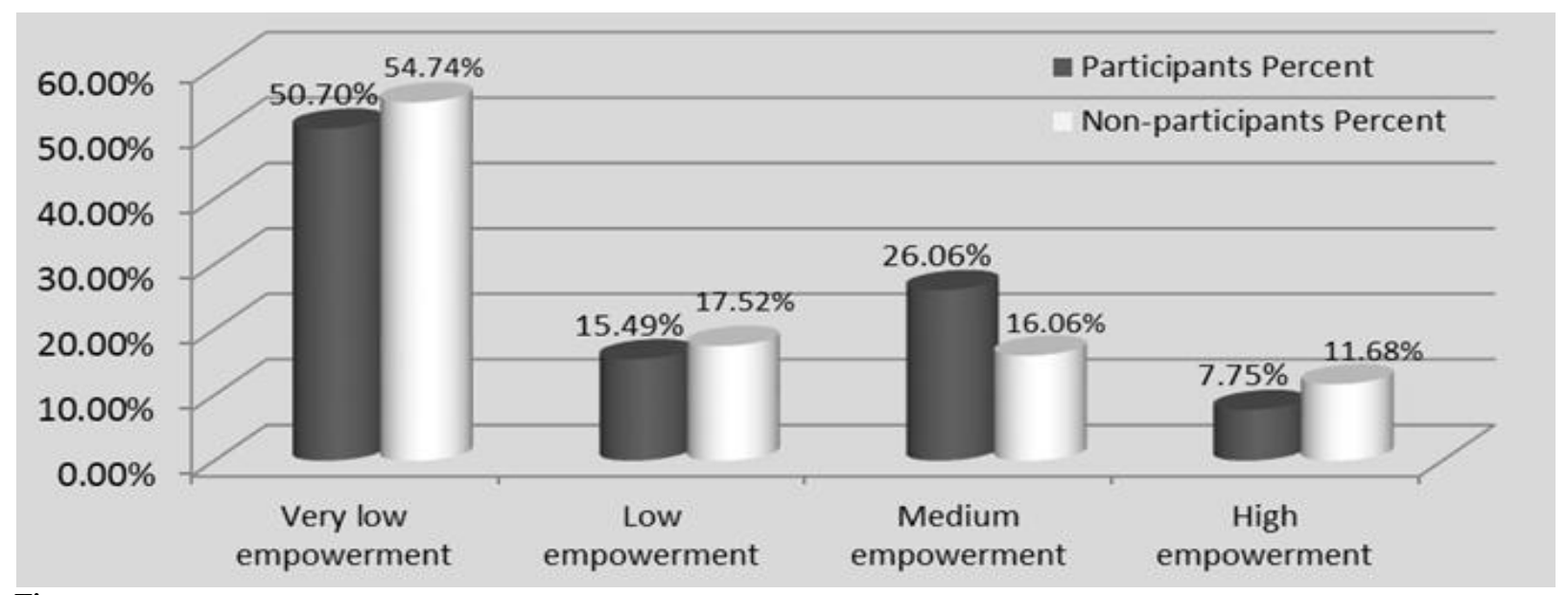

Figure-2.

Categories of women according to economic empowerment status.

Source: Field survey.

\subsection{Social Empowerment Status}

The total social empowerment score of a woman was also computed by adding the scores obtained from all measures of social empowerment. Possible scores ranged from 0 to 93. Table 4 shows respondent's classifications into four categories based on empowerment scores.

This study also reveals that participants also achieved a significant improvement in medium level of social empowerment Table 4. Total 28.17 percent of the participants reached to the level of medium 
social empowerment that is higher than the non-participants (22.63\%). Only 6.34 percent of the participants were able to elevate their status to high empowerment that was lower than the nonparticipants $(8.03 \%)$. The majority of the both groups remained in or demoted their status to the "very low level of empowerment" category.

Table-4.

Categories of women according to social empowerment.

\begin{tabular}{l|c|c|c|c}
\hline \multirow{2}{*}{ Categories and score range } & \multicolumn{2}{|c|}{ Participants } & \multicolumn{2}{c}{ Non-participants } \\
\cline { 2 - 5 } & Frequency & Percentage & Frequency & Percentage \\
\hline Very low empowerment (up to 20$)$ & 66 & 46.48 & 74 & 54.01 \\
\hline Low empowerment (21 to 40) & 27 & 19.01 & 21 & 15.33 \\
\hline Medium empowerment (41 to 60) & 40 & 28.17 & 31 & 22.63 \\
\hline High empowerment (Above 60) & 9 & 6.34 & 11 & 8.03 \\
\hline Total & 142 & 100 & 137 & 100 \\
\hline
\end{tabular}

Source: Field survey.

\subsection{Statistical Relation between Microfinance Program and Women's Empowerment}

Statistical relationship among the scores of selected empowerment indicators and microfinance program participation were determined by using Logistic regression model. The theory suggest that if Likelihood Ratio is $(\mathrm{LR})>10$, we can accept the results of logistic regression. Likelihood Ratio for the model 16.39 suggests that the model is robust and the independent variables influence the dependent variable properly Table 5. Similarly, the value of $\mathrm{R}$ - square indicate that there is a reasonable explanatory relation between the dependent and independent variables.

Table-5.

Result of Logit regression on microfinance program and women's empowerment.

\begin{tabular}{l|c|c|c}
\hline Factors & Coefficients & Odds Ratio & P-value \\
\hline Financial decision making & 0.118 & 1.125 & 0.025 \\
\hline Independent purchasing capability & 0.073 & 1.076 & 0.019 \\
\hline Economic security & 0.084 & 1.088 & 0.034 \\
\hline Decision making in social and family affairs & 0.142 & 1.153 & 0.044 \\
\hline Comparative freedom in family & 0.231 & 1.260 & 0.000 \\
\hline Cosmopoliteness & 0.161 & 1.175 & 0.089 \\
\hline Community, social and political participation & 0.041 & 1.042 & 0.001 \\
\hline Likelihood ratio & & 16.39 & \\
\hline Pseudo R 2 & & 0.46 & \\
\hline Source: Field survey.
\end{tabular}

Source: Field survey.

The result also shows that, six variables were positively and significantly correlated with the microfinance program participation. Only, one variable cosmopoliteness showed positive but weakly

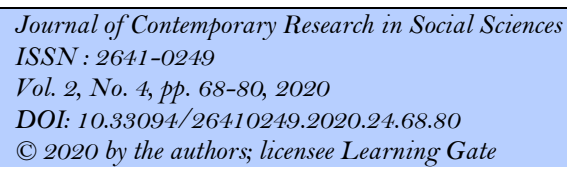


significant relationship with microfinance program participation. A significant positive relation between comparative freedom in family and program participation implies that microfinance program increases a women's freedom in the family (Cao, Sarker, \& Sun, 2019). Community, social and political participation, financial decision making, independent purchasing capability, economic security and decision making in social and family affairs also holds the same implication (Sarker et al., 2020b).

\section{Conclusions and Policy Implications}

Since women are almost half of the total population of Bangladesh so without their active involvement in economic activities it is hardly possible to achieve the goal of eradicating poverty. Microfinance is considered as an important tool for empowering rural poor women and thus enable them to take part in economic activities. Therefore, present study examines the effectiveness of microfinance programs to empower the extreme rural poor women using data collected from northern part of Bangladesh.

Study reveals that empowerment status of extreme poor women in the study areas improves over time with participation in microfinance program, but the magnitude is not satisfactory. The majority of the respondents are found to remain in the 'very low level of empowerment' category. Microfinance program are found to empower the extreme poor women in 'medium scale'. Noteworthy, extent of empowerment are appeared to be the highest among women, who utilizes their loans properly to generate independent income. Microfinance program participants get opportunity to meet and negotiate with the MFI representatives; to participate in the group meetings, in training programs and to go to MFI's office for receiving loan. Importantly, these enable many of them to use fully or partially the borrowing money to generate independent income activities. Women's income earnings ability improve their relative importance to their family. Thus microfinance programs help the participants to improve their economic and social empowerment status compared to non-participants.

MFIs should emphasis more on using borrowed money by the women borrower in independent income generating activities. It is also important to provide entrepreneurship training to the women in order to improve their skills in the business area. In that case, regulatory authority should provide policy support and create legal obligation to promote women entrepreneurship development program by the MFIs.

\section{References}

Alam, G. M. M. (2016). An assessment of the livelihood vulnerability of the riverbank erosion hazard and its impact on food security for rural households in Bangladesh. PhD Disssertation, University of Southern Queensland, Toowoomba, Australia.

Alam, K., Monirul Alam, G., \& Mushtaq, S. (2018). Drivers of food security of vulnerable rural households in Bangladesh: implications for policy and development. South Asia Economic Journal, 19(1), 43-63.

BBS. (2014). Statistical pocketbook. Dhaka, Bangladesh: BBS.

Bekele, E., \& Muchie, M. (2009). Promoting micro, small and medium Enterprises (MSMEs) for sustainable rural livelihood. Diiper Research Series, 11, 1-24.

Binaté Fofana, N., Antonides, G., Niehof, A., \& van Ophem, J. A. C. (2015). How microfinance empowers women in côte d'Ivoire. Review of Economics of the Household | Standard Journal, 13, 1023-1041.Available at: https://doi.org/10.1007/s $11150-015-9280-2$.

Cao, Q., Sarker, M. N. I., \& Sun, J. (2019). Model of the influencing factors of the withdrawal from rural homesteads in China: Application of grounded theory method. Land use Policy, 85, 285-289.Available at: https://doi.org/10.1016/j.landusepol.2019.04.013.

Cramer, C. (2003). Does inequality cause conflict? Journal of International Development - Wiley Online Library, 15, 397412.Available at: https://doi.org/10.1002/jid.992.

Eze, D. E. (2019). Microfinance programs and domestic violence in northern cameroon; The case of the familial rural income improvement program. Review of Economics of the Household, 17(3), 947-967.

Garrity, P., \& Martin, C. (2018). Developing a microfinance model to break the cycle of poverty. Bus. Horiz, 61, 937947.Available at: https://doi.org/10.1016/j.bushor.2018.07.002.

Ghosh, S., \& Bhandari, A. K. (2014). Microfinance and rural entrepreneurship: An assessment, in: Bhandari, a.k., kundu, a. (eds.), microfinance, risk-taking behaviour and rural livelihood (pp. 49-67). New Delhi: Springer India.

Ghosh, M. (2013). Microfinance and rural poverty, in: Liberalization, Growth and regional disparities in India (pp. 167-184). India: Springer. 
Goetz, A. M., \& Gupta, R. S. (1996). Who takes the credit? Gender, power, and control over loan use in rural credit programs in Bangladesh. World Development - Journal - Elsevier, 24, 45-63.Available at: https://doi.org/10.1016/0305$750 \mathrm{X}(95) \mathrm{O0} 124-\mathrm{U}$.

Hoque, M. E. (2014). Impact of micro-credit of grameen bank in reducing rural poverty: A study in two upazillas of Sylhet district. Research on Humanities and Social Sciences, 4(22), 8-26.

Hulme, D., \& Moore, K. (2007). Why has microfinance been a policy success in Bangladesh? In: Development success (pp. 105139). London: Palgrave Macmillan.

Hultberg, L. (2008). Women empowerment in Bangladesh: A study of the village pay phone program. Master Thesis, Jönköping University, Jönköping, Sweden.

Islam, M. S. (2014). Women's empowerment in Bangladesh: A case study of two NGOs. SSRN Electron. J. 23.Available at: https://doi.org/10.2139/ssrn.2502890.

Kamruzzaman, M. M., Alanazi, S. A., Alruwaili, M., Alshammari, N., Siddiqi, M. H., \& Huq, M. E. (2020). Water resource evaluation and identifying groundwater potential zones in arid area using remote sensing and geographic information system. Journal of Computer Science and Technology, 16, 266-279.Available at: https://doi.org/10.3844/jcssp.2020.266.279.

Khanam, D., Mohiuddin, M., Hoque, A., \& Weber, O. (2018). Financing micro-entrepreneurs for poverty alleviation: a performance analysis of microfinance services offered by BRAC, ASA, and Proshika from Bangladesh. Journal of Global Entrepreneurship Research, 8(1), 1-17.

Khatun, M. N. (2017). Credit utilization and repayment behabiour of the farmers: An empirical study from Kushtia district of Bangladesh. Journal of the Sylhet Agricultural University, 1(2), 279-287.

Lavoori, V., \& Paramanik, R. N. (2014). Microfinance impact on women's decision making: A case study of Andhra Pradesh. Journal of Global Entrepreneurship Research Citation Style, 4, 1-13.Available at: https://doi.org/10.1186/s40497-0140011-6.

Malhotra, A., \& Schuler, S. R. (2005). Women's empowerment as a variable in International Development. World Bank.org, $71-$ 88.Available at: https://doi.org/10.1596/0-8213-6057-4.

Mersland, R., Nyarko, S. A., \& Szafarz, A. (2019). Do social enterprises walk the talk? Assessing microfinance performances with mission statements. Journal of Business Venturing insights Abbreviation - Paperpile.Available at: https://doi.org/10.1016/j.jbvi.2019.e00117.

Mohindra, K., Haddad, S., \& Narayana, D. (2008). Can microcredit help improve the health of poor women? Some findings from a cross-sectional study in Kerala, India. International Journal for Equity in Health, 7(1), 1-14.Available at: https://doi.org/10.1186/1475-9276-7-2.

Murshid, N. S., \& Ball, A. (2018). Examining women's physical mobility and microfinance participation in Bangladesh: Results from a nationally representative sample. Womens. Stud. Int. Forum, 69, 33-39.Available at: https://doi.org/10.1016/j.wsif.2018.04.009.

Nawaz, F. (2019). Microfinance and women's empowerment in Bangladesh Unpacking the Untold Narratives (Vol. 127): Palgrave Pivot, XIII.

Pitt, M. M., \& Khandker, S. R. (1996). Household and intrahousehold impact of the Grameen bank and similar targeted credit programs in Bangladesh (pp. 25-79). World Bank Discussion Paper. World Bank, Washington DC, USA.

Richardson, R. A. (2018). Measuring women's empowerment: A need for context and caution. Lancet Glob. Heal. 6, e30.Available at: https://doi.org/10.1016/S2214-109X(17)30460-6.

Roodman, D., \& Morduch, J. (2014). The impact of microcredit on the poor in bangladesh: Revisiting the evidence. Journal of Development Studies, 50, 583-604.Available at: https://doi.org/10.1080/00220388.2013.858122.

Sarker, M. N. I., Hossin, M. A., Wu, M., Alam, G. M., Shafi, M., Pervez, A. K., \& Rahman, A. (2018). Determinants and pattern of urbanization and counter-urbanization: The Case of South Asia. Journal of Social Science Research, 4, 802812.Available at: https://doi.org/10.32861/jssr.412.802.812.

Sarker, M. N. I., Wu, M., Alam, G. M. M., \& Shouse, R. C. (2020a). Life in riverine islands in Bangladesh: Local adaptation strategies of climate vulnerable riverine island dwellers for livelihood resilience. Land use policy, 94, 104574.Available at: https://doi.org/10.1016/j.landusepol.2020.104574.

Sarker, M. N. I., Yang, B., Lv, Y., Enamul, M., \& Kamruzzaman, M. M. (2020b). Climate change adaptation and resilience through big data. International Journal of Advanced Computer Science, 533-539.Available at: https://doi.org/10.14569/IJACSA.2020.0110368.

Shafi, M., Sarker, M. N. I., \& Junrong, L. (2019). Social network of small creative firms and its effects on innovation in developing countries. SAGE Open 9, 215824401989824.Available at: https://doi.org/10.1 177/2158244019898248.

Singh, V., \& Padhi, P. (2019). Factors influencing outreach performance of microfinance sector in India. Asia-Pacific J. Manag. Res. Innov, 15, 162-176.Available at: https://doi.org/10.1177/2319510X19883705.

Sofi, F. J., \& Sumaira. (2016). Microfinance and poverty alleviation: A conceptual framework with special emphasis on j \&k region. Asia-Pacific Journal of Management Research and Innovation, 12(3-4), 271-281.

Weber, O., \& Ahmad, A. (2014). Empowerment through microfinance: The relation between loan cycle and level of empowerment. World Development - Journal, 62, 75-87.Available at: https://doi.org/10.1016/j.worlddev.2014.05.012.

Zafarullah, H., \& Nawaz, F. (2019). Pathways to women's empowerment in Bangladesh. Asian Educ. Dev. Stud, 8, 387404.Available at: https://doi.org/10.1108/AEDS-11-2018-0168.

Journal of Contemporary Research in Social Sciences
ISSN : $264.1-0249$
Vol. 2, No. 4, pp. $68-80,2020$
DOI: $10.33094 / 26410249.2020 .24 .68 .80$
C) 2020 by the authors; licensee Learning Gate


Appendix-1.

Items used to measure each of the empowerment indicators.

\begin{tabular}{|c|c|}
\hline \multicolumn{2}{|c|}{ Items used to measure each indicators of economic empowerment } \\
\hline Financial decision making (1) & Independent purchasing capability (2) \\
\hline Daily household expenditure .i & Purchasing daily essentials .i \\
\hline Lending and borrowing to/from others .ii & \multirow{2}{*}{$\begin{array}{l}\text { Purchasing small personal items, such .ii } \\
\text { as, cosmetics, glass bangles, and } \\
\text { cookeries }\end{array}$} \\
\hline Leasing or selling/buying land; and .iii & \\
\hline Use of savings .iv & \multirow[t]{2}{*}{ Buying clothes and sweets for children .iii } \\
\hline Economic security (3) & \\
\hline $\begin{array}{l}\text { Ownership of house or homestead or } \\
\text { cultivable land in her name }\end{array}$ & Buying gifts for social functions .iv \\
\hline $\begin{array}{ll}\text { Possessing income generating assets, such } & \text {.ii } \\
\text { as a rickshaw, boat, vehicle and machineries } & \\
\end{array}$ & Buying medicine \\
\hline $\begin{array}{l}\text { Having cash savings or ability to manage .iii } \\
\text { worth of Tk.1000.00 instantly in } \\
\text { emergency incidences }\end{array}$ & $\begin{array}{l}\text { Purchasing Sharees for family members } \\
\text { including herself }\end{array}$ \\
\hline $\begin{array}{l}\text { Running business with personal savings or } \text {.iv } \\
\text { lending money from personal savings }\end{array}$ & Buying household furniture .vii \\
\hline $\begin{array}{l}\text { Access to household income without } \cdot v \\
\text { husband's prior knowledge }\end{array}$ & $\begin{array}{l}\text { Buying and selling of land and other } \\
\text { durable assets }\end{array}$ \\
\hline \multicolumn{2}{|c|}{ Items used to measure each indicators of economic empowerment } \\
\hline Decision making in social and family affairs (1) & $\begin{array}{l}\text { Relative freedom from domination and (2) } \\
\text { violence within the family }\end{array}$ \\
\hline The education of children. i & Assaulted by her husband .i \\
\hline Family health issues .ii & $\begin{array}{l}\text { Cash savings taken from her against her } \\
\text { will }\end{array}$ \\
\hline The social and religious events celebration & $\begin{array}{l}\text { Jewelry, livestock, or poultry taken from } \\
\text { her against her will }\end{array}$ \\
\hline Social program and guest's choice. .iv & Restriction visiting relative house $\quad$ iv \\
\hline $\begin{array}{l}\text { Selecting and using family planning } \cdot v \\
\text { methods }\end{array}$ & $\begin{array}{l}\text { Prevented from working outside the } \quad . v \\
\text { home }\end{array}$ \\
\hline $\begin{array}{l}\text { Constructing and repairing of dwelling .vi } \\
\text { houses }\end{array}$ & $\begin{array}{l}\text { Husband has sole power to initiate } \\
\text { divorce at any time }\end{array}$ \\
\hline Decision on son's or daughter's marriage .vii & \\
\hline (3) Cosmopoliteness & $\begin{array}{l}\text { (4) Community, social and political } \\
\text { participation }\end{array}$ \\
\hline Number of visit to market places & \multirow[t]{2}{*}{$\begin{array}{l}\text { Participation in social programs like } \\
\text { marriage, birthday party etc. }\end{array}$} \\
\hline Number of visit to the health centers .ii & \\
\hline $\begin{array}{l}\text { Number of visit to the local NGO and MFI } \\
\text { branch offices }\end{array}$ & Helping neighbors in crisis situations .ii \\
\hline $\begin{array}{l}\text { Number of visit to friend's and relative's } \text {.iv } \\
\text { houses outside the home village }\end{array}$ & Participation to emergency management \\
\hline $\begin{array}{l}\text { Number of visit to cinema hall for watching } \\
\text { movies }\end{array}$ & $\begin{array}{l}\text { Various meetings and arbitrations } \\
\text { participation in village. }\end{array}$ \\
\hline Number of visit to the upazila headquarter .vi & Participation to arbitration related \\
\hline
\end{tabular}




\begin{tabular}{l|ll}
\hline Items used to measure each indicators of economic empowerment \\
\hline Number of visit to the neighboring upazilas .vii & $\begin{array}{l}\text { Participation in votes in local and .vi } \\
\text { national elections. }\end{array}$ \\
\hline $\begin{array}{l}\text { Number of visit to the local district .viii } \\
\text { headquarter }\end{array}$ & $\begin{array}{l}\text { Campaigning for a political candidate of } \\
\text { her own choice }\end{array}$ \\
\hline Number of visit to other districts .ix & $\begin{array}{l}\text { Participating in local government } \\
\text { election as a candidate }\end{array}$ \\
\hline Number of visit to the capital city .x & & \\
\hline
\end{tabular}

